\title{
Oral lichen planus and oral lichenoid reactions: a retrospective evaluation of patch test results with dental series
}

\section{Oral liken planus ve oral likenoid reaksiyonlar: Dental seri yama testi sonuçlarının retrospektif olarak değerlendirilmesi}

\author{
Burcu Aydemir $^{1}$, Leyla Baykal Selcuk ${ }^{1}\left[\right.$, Deniz Aksu Arica ${ }^{1}$, Ali Osman Metintas ${ }^{1}$ (]) \\ ${ }^{1}$ Dept. of Dermatology, Karadeniz Technical University Faculty of Medicine, Trabzon, Turkey
}

\section{Abstract}

Objective Oral lichen planus (OLP) and oral lichenoid reactions (OLR) may occur secondary to dental procedures. Patch testing with the dental series is a simple diagnostic method that can guide the identification of the relevant allergen. In this study, it was aimed to evaluate the patch test results with dental series in OLP and OLR patients.

Methods A retrospective review of the medical records of patients who were clinically and/or histopathologically diagnosed with OLP or OLR and, who underwent dental series patch testing at our dermatology clinic in between January 2015 and January 2021 was performed.

Results In total, 36 patients with a diagnosis of OLP ( $n=14,38.9 \%)$ or OLR ( $n=22,61.1 \%$ ) were included, 15 of whom $(41.7 \%)$ had positive patch test results. The mean age at presentation was 54.6 years (range 28-72 years). The duration of the disease was 21.9 (range 1-144 months) months on average. Positive findings on patch tests were approximately three times higher in OLR patients than in OLP patients. Gold(I) sodium thiosulfate dihydrate was the most frequent positive reaction $(n=6)$ detected against. Habits (smoking, alcohol) and comorbidities were not significantly associated with the patch test results.

Conclusion Detection of allergens with patch test is a helpful diagnostic method for effective control of the disease in both OLP and OLL patients. We think that the detection of contact allergies with patch testing may guide decisions regarding related changes such as dental restorations.

Key words: dental series, oral lichen planus, oral lichenoid reactions, patch test

$\ddot{\mathrm{O} z}$

Amaç Oral liken planus (OLP) ve oral likenoid reaksiyonlar (OLR) dental işlemlere ikincil ortaya çıkabilir. Dental seri yama testi, ilgili alerjenin belirlenmesine rehberlik edebilecek basit bir tanı yöntemidir. Bu çalışmada OLP ve

Corresponding author: Burcu Aydemir, Dept. of Dermatology, Karadeniz Technical University Faculty of Medicine, Trabzon, Turkey, Phone: +90 553 8520267, E-mail: burcaydemr@gmail.com

Received: 22 March 2021 Accepted: 30 March 2021

Conflicts of Interest: None

Funding: None

How to cite this article: Aydemir B, Baykal Selcuk L, Aksu Arica D, Metintas AO. Oral lichen planus and oral lichenoid reactions: a retrospective evaluation of patch test results with dental series. Mucosa 2021;4:17-22

(c) (i) (2) This work is licensed under a Creative Commons Attribution-NonCommercial 4.0 International License. 
OLR hastalarında dental seri yama testi sonuçlarının değerlendirilmesi amaçlanmıştır.

Yöntem Klinik ve/veya histopatolojik olarak OLP veya OLR tanısı almış ve Ocak 2015 ile Ocak 2021 arasında dermatoloji kliniğimizde dental seri yama testi yapılan hastaların tıbbi kayıtlarının retrospektif bir incelemesi yapıldı.

Bulgular Toplamda, OLP ( $n=14, \% 38.9)$ veya OLR ( $\mathrm{n}=22$, \%61.1) tanısı alan 36 hasta dahil edildi, bunlarm 15'inde (\% 41.7) yama testi pozitifti. Başvuru anındaki ortalama yaş 54.6 yıldı (28-72 yaş aralığı). Hastalık süresi ortalama 21.9 aydı (1-144 ay aralığı). Yama testlerindeki pozitif bulgular, OLR hastalarında OLP hastalarına göre yaklaşık üç kat daha yüksekti. En sık pozitif reaksiyon $(n=6)$ altın (I) sodyum tiyosülfat dihidrata karşı tespit edildi. Alışkanlıklar (sigara, alkol) ve komorbiditeler, yama testi sonuçlarıyla önemli ölçüde ilişkili değildi.

Sonuç Yama testi ile temas alerjilerinin tespitinin, diş restorasyonları gibi ilişkili değişikliklere yönelik kararlara rehberlik edebileceğini düşünüyoruz.

Key words: dental seri, oral liken planus, oral likenoid reaksiyon, yama testi

\section{Introduction}

Lichen planus is a chronic inflammatory mucocutaneous disease, which most commonly affects the skin, genitalia and oral mucous membranes. ${ }^{1}$ Oral lichen planus (OLP) is a common variant of lichen planus. Although there is no comprehensive epidemiological study of OLP prevalence, recent review articles have shown prevalences ranging from $0.5 \%$ to $4 \% .^{2-4}$ OLP most commonly occurs in middle-aged adults, and women are more frequently affected than men. ${ }^{5}$

The most common theory for the pathogenesis of OLP is that an immune reaction against an exogenous or endogenous antigen triggers the onset of the disease. Although the etiology is unknown; various factors such as genetic background, dental materials, drugs, infectious agents - bacterial and viral infections, autoimmune diseases, immunodeficiency, food allergies, stress, habits, trauma, diabetes and hypertension, malignant neoplasms, and bowel disease have been proposed. ${ }^{6}$

The buccal mucosa, tongue and gingiva are commonly affected by OLP. It presents as symmetrical or multiple lesions. There are six variants such as reticular, papular, plaque-like, erosive, atrophic and bullous types. ${ }^{7}$ Patients may complain about pain, a burning sensation or swelling. It may be concomitant with cutaneous and genital lichen planus. ${ }^{8}$

Lichenoid changes which occur in the oral mucosa as a result of dental restorations, drugs, systemic diseases and allergies to food or flavouring are referred as oral lichenoid reactions (OLR). ${ }^{9}$ OLR is rare and most commonly associated with dental amalgam, the most widely used filling material in the world. ${ }^{2}$ OLR is a type IV or delayed hypersensitivity reaction. Lesions caused by hypersensitivity to amalgam or its constituents resemble those of OLP. The lesions can be asymptomatic, or when ulcerated, painful; especially when eating hot, salty, spicy foods. Unlike lichen planus, which usually has a symmetrical distribution in the mouth, the OLR can typically be unilateral and asymmetrical depending on the location of the dental materials. ${ }^{10}$

These clinical features and the epicutaneous patch test for dental materials are helpful diagnostic methods in distinguishing OLP and OLR. It can still be difficult for the clinician to make a clear distinction if dental restorations are widespread in the mouth. Both OLP and OLR secondary to dental restorations can be painful. ${ }^{7}$ The results have the potential to guide patients and physicians in making the decision to change dental restorations. Elimination of the allergen in OLR may result in clinical improvement and therefore it is important to distinguish the two conditions. $^{11}$

In this retrospective study, we aimed to evaluate the patch test results with dental series in the patients with OLP or OLR in order to specify the association of the clinical findings and the patch test results. 


\section{Methods}

This study was approved by the Institutional Ethics (Date:15.03.2021, number:2021/77). We retrospectively evaluated patients who were clinically or histopathologically diagnosed with OLP or OLR with a patch test result of dental series performed between January 2015 and January 2021 at the Department of Dermatology, Faculty of Medicine in Karadeniz Technical University. Demographic characteristics (gender, age, etc.), disease-related characteristics (duration, subtype, clinical features), habits (smoking, alcohol), comorbidities (hyperlipidemia, Hepatitis B and C infection, cardiovascular disease, neuropsychiatric disease, autoimmune disease), history of dental procedures were noted from the patients records. In patients with oral lichen planus who had concomitant cutaneous or genital lichen planus, these involvements were also recorded.

All patients were patch-tested using European dental screening (DS-1000) serial. By using standard methods, 35 antigens were placed on the back of the patients, and fixed by using Finn chambers and taped. Evaluations were performed approximately 48 and 96 hours after the application of antigens. In the evaluation, if an erythematous and/or palpable, but not vesicular reaction were seen, it is pointed as " $1+$ ". Two points for edematous or vesicular reactions, and $3+$ points for dissemination, bullous or ulcerative reactions were given.

In statistical analysis, descriptives were expressed as mean \pm standard deviation (SD) for continuous variables and as percentages (\%) for categorical variables.

\section{Results}

Patch tests were performed in 36 patients diagnosed with OLP or OLL. In 14 (38.9\%) of these patients, the diagnosis of OLP was clinically or histologically confirmed. Table 1 summarizes the demographics, comorbidities, disease duration, results of patch test, clinical morphology, history of dental procedure in the 36 patients diagnosed with OLL or OLP.
Within this retropective cohort, there were 33 females and 3 male. The mean age at presentation was $54.60 \pm 12.30$ years (range $28-72$ years). The duration of the disease ranged from 1 to 144 months $(21.90 \pm 31.52$ months). Four (18.1\%) of the 22 patients were smokers. The predominant type of the clinical morphologic lesions was non-erosive type including mostly reticular lesions $(n=21,58.3 \%)$. The most common comorbidities were detected as hyperlipidemia and neuropsychiatric diseases $(n=8$, $22.2 \%$ ). Others, in order of frequency, included cardiovascular diseases $(\mathrm{n}=5,13.9 \%)$, autoimmune disease $(n=5,13.9 \%)$ and hepatitis $B$ infection $(n=1$, $2.7 \%)$. None of the patients had hepatitis $C$ infection. Seventy-five per cent of the patients $(n=27)$ had a history of dental procedures before the lesions started. In most of these patients, the region of the dental procedure and lesions were compatible $(n=25,69.4 \%)$. In addition, of the 14 patients with OLP, four (28.6\%) had concomitant cutaneous lichen planus and one (7.1\%) had concomitant genital lichen planus.

Of the 36 patients, 15 (41.7\%) had positive findings according to the results of dental patch test readings. In this group, only four (26.6\%) of the patients with positive results were diagnosed as OLP. When compared proportionally, positive findings on patch tests were nearly three times greater in patients with OLR.

Eight (53.3\%) of the patients with positive results had a positive reaction to more than one substance in the patch test. The most frequent detected positive reaction $(n=6)$ against was gold(I) sodium thiosulfate dihydrate. It was one of the most common substances with positive reactions in patients with OLP. The others were cobalt(II)chloride hexahydrate and copper(II) sulfate pentahydrate.

Regarding the patients with OLL, the most frequent positive reaction was detected against to gold(I)sodium thiosulfate dihydrate. Other allergens that were detected included cobalt(II)chloride hexahydrate, nickel(II)sulfate hexahydrate, eugenol ,copper(II)sul- 
Table 1. Demographic and clinical features of the patients with oral lichenoid reactions and oral lichen planus

\begin{tabular}{|c|c|}
\hline Demographic and clinical features & n (\%) \\
\hline Age $($ mean \pm SD $)$ & $54.60 \pm 12.30$ \\
\hline Sex (female/male) & $33 / 3$ \\
\hline \multicolumn{2}{|l|}{ Diagnosis } \\
\hline OLR* & $22(61.1)$ \\
\hline OLP $^{* *}$ & $14(38.9)$ \\
\hline Smoker & $4(18.1)$ \\
\hline Alcohol consumption & $0(0.0)$ \\
\hline \multicolumn{2}{|l|}{ Comorbidities } \\
\hline Hepatitis B & $1(2.7)$ \\
\hline Hepatitis C & $0(0.0)$ \\
\hline Hyperlipidemia & $8(22.2)$ \\
\hline Cardiovascular disease & $5(13.9)$ \\
\hline Neuropsychiatric disease & $8(22.2)$ \\
\hline Autoimmune disease & $5(13.9)$ \\
\hline $\begin{array}{l}\text { Disease duration, (mean } \pm S D) \text {, } \\
\text { months }\end{array}$ & $21.90 \pm 31.52$ \\
\hline \multicolumn{2}{|l|}{ Patch test positivity } \\
\hline $\mathrm{N}, \mathrm{N}$-dimethyl-4-toluidine & $1(2.7)$ \\
\hline Potassium dichromate & $1(2.7)$ \\
\hline Mercury & $2(5.5)$ \\
\hline Cobalt (II) chloride hexahydratel & $4(11.1)$ \\
\hline $\begin{array}{l}\text { Gold (I) sodium thiosulfate } \\
\text { dihydrate }\end{array}$ & $6(16.6)$ \\
\hline Nickel (II) sulfate hexahydratel & $3(8.3)$ \\
\hline Eugenol & $3(8.3)$ \\
\hline Formaldehyde & $1(2.7)$ \\
\hline Copper(II)sulfate pentahydrate & $3(8.3)$ \\
\hline Methylhydroquinone & $1(2.7)$ \\
\hline Palladium(II)chloride & $1(2.7)$ \\
\hline Dimethylamınoethyl methacrylate & $1(2.7)$ \\
\hline Drometrizole & $1(2.7)$ \\
\hline $\begin{array}{l}\text { Sodium tetrachloropalladate(II) } \\
\text { hydrate }\end{array}$ & $2(5.5)$ \\
\hline Glutaral & $1(2.7)$ \\
\hline Negative & $21(58.3)$ \\
\hline \multicolumn{2}{|l|}{ Clinical morphology } \\
\hline Erosive & $15(41.7)$ \\
\hline Non-erosive & $21(58.3)$ \\
\hline Dental procedure history & $27(75.0)$ \\
\hline $\begin{array}{l}\text { Dental procedure and localization } \\
\text { compliance }\end{array}$ & $25(69.4)$ \\
\hline
\end{tabular}

*OLR, oral lichenoid reaction; ** OLP, oral lichen planus fate pentahydrate, copper(II)sulfate pentahydrate, mercury, sodium tetrachloropalladate(II) hydrate, n, n-dimethyl-4-toluidine, potassium dichromate, formaldehyde, methylhydroquinone, palladium(II) chloride, dimethylaminoethyl methacrylate, drometrizole and glutaral.

When we examine the positive results in detail, the number of patients with positive reactions against to sodium tetrachloropalladate (II) hydrate and cobalt (II) chloride hexahydrate was similar in both groups. Patients with a positive reaction against to copper (II) sulfate pentahydrate were twice as much in the OLP group compared to the other. The number of patients with a positive reaction against to gold (I) sodium thiosulfate dihydrate was twice as high in the OLR group compared to OLP. All of the patients with positive reactions to other allergens were in the OLR group.

\section{Discussion}

Oral lichen planus is a variant of lichen planus that affects the oral mucosa. The diagnosis of OLP is usually made by clinical and histological examination, but when classical lesions are seen, clinical appearance is often sufficient. There are many oral lichenoid lesions, especially OLR, which can be confused with OLP in the differential diagnosis. Besides systemic medications, dental restorative materials such as amalgam, gold and nickel may also be associated with OLR, and the patch tests with dental series contribute the etiology. ${ }^{12}$

The rate of positive patch test results of dental series in OLP or OLR ranges from $14 \%$ to $70 \% .^{10,13}$ The rate we found $(41.7 \%)$ is in this wide range. In our study, gold(I)sodium thiosulfate dihydrate was the most frequent allergen in both groups. In the study of Tiwari et al., a total of 68 patients with a diagnosis of OLP were evaluated, and 39 (79\%) of the patients had positive findings in the patch test. Gold (48\%) were the most common allergens that patients tested positive. Other common allergens were mercury, nickel, copper, potassium dichromate, and methylhydroquinone. ${ }^{14}$ Koch et al. evaluated the frequency of sensitivity to 
metal salts in 194 patients (OLR patients partially adjacent to amalgam fillings, OLP not in close contact with amalgam, other oral diseases, mouth complaints, control group) The frequency of sensitivity to inorganic mercury, gold sodium thiosulfate and palladium chloride was found to be high in all groups. ${ }^{15}$

Previous studies have not shown a clear relationship between comorbidities and patch test results in patients with OLP or OLR. While OLP was associated with hepatitis $C$, hepatitis $C$ was not detected in any patients in both groups of our study.

In the study of Şahin et al., thirty-three patients diagnosed with OLP or OLL were evaluated. In patients with a positive patch test result, the non-erosive type was the most common clinical morphology. ${ }^{12}$ In our study, patch test positivity was more frequent in the non-erosive type than in the erosive forms.

Additionally, in OLP patients, $75 \%$ of those with a positive patch test had no prior history of dental procedures. Most of the OLR patients (\%91.6) had a history of dental procedures before the lesions. This result supports a contact dermatitis in OLR patients caused by contact with dental materials. The positive reactions obtained in the patch test support that OLR develops as a result of the hypersensitivity reaction, but for a definite relationship, it is necessary to show that the lesions regress after removing the relevant dental material. ${ }^{16}$

The limitations of the study include the small number of the patients, and the lack of histologically confirmed diagnosis in all OLP patients.

Both OLP and OLR may occur secondary to dental procedures, and lesions may be painful. It is an important cause of morbidity and lesions may also carry a risk of malignant transformation into squamous cell carcinomas. ${ }^{7}$ Identifying and removing relevant materials is important in preventing this morbidity.

In conclusion, we suggest that the detection of allergens with patch test will contribute the etiology of the disease, and help the effective control of the disease in both OLP and OLL patients.
Ethics Committee approval:

(Date:15.03.2021, number:2021/77)

Informed consent: They are obtained.

Peer-review: Externally peer-reviewed

Authorship contributions:

Conception and design, or analysis and interpretation of data: BA, LBS, DAA, AOM

Drafting the manuscript or revising the content: BA, LBS, DAA, AOM

Final approval of the version to be published: BA, LBS, DAA

\section{References}

1. McCartan BE, Healy CM. The reported prevalence of oral lichen planus: a review and critique. J Oral Pathol Med 2008;37:447-53.

2. Al-Hashimi I, Schifter M, Lockhart P, et al. Oral lichen planus and oral lichenoid lesions: diagnostic and therapeutic considerations. Oral Surg Oral Med Oral Pathol Oral Radiol Endod 2007;103:1-12.

3. Lodi G, Scully C, Carrozzo M, et al. Current controversies in oral lichen planus: report of an international consensus meeting. Part 2. Clinical management and malignant transformation. Oral Surg Oral Med Oral Pathol Oral Radiol Endod 2005;100:164-78.

4. Scully C, Beyli M, Ferreiro M, et al. Update on oral lichen planus; etiopathogenesis and management. Crit Rev Oral Biol Med 1998;9:86-122.

5. Eisen D. The clinical features, malignant potential, and systemic associations of oral lichen planus: a study of 723 patients. J Am Acad Dermatol 2002;46:207-14.

6. Roopashree MR, Gondhalekar RV, Shashikanth MC, George J, Thippeswamy SH, Shukla A. Pathogenesis of oral lichen planus a review. J Oral Pathol Med 2010;39:729-34.

7. Ismail SB, Kumar SKS, Zain RB. Oral lichen planus and Lichenoid reactions; etiopathogenesis, diagnosis, management and malignant transformation. J Oral Sci 2007;49:89-106.

8. Eisen D. The clinical manifestations and treatment of oral lichen planus. Dermatol Clin 2003;21:79-89.

9. Dudhia BB, Dudhia SB, Patel BS, et al. Oral lichen planus to oral lichenoid lesions: evolution or revolution. J. Oral Maxillofac. Pathol 2015;19:364-70.

10. Thornhill MH, Pemberton MW, Simmons RK, 
Theaker ED. Amalgam contact hypersensitivity lesions and oral lichen planus. Oral Surg Oral Med Oral Path 2003;95:291-9.

11. Laine J, Kalimo K, Happonen RP. Contact allergy to dental restorative materials in patients with oral lichenoid lesions. Contact Dermatitis 1997;36:141-6.

12. Sahin EB, Cetinozman F, Avcu N, Karaduman A. Evaluation of patients with oral lichenoid lesions by dental patch testing and results of removal of the dental restoration material. Turkderm 2016;50:150-6.

13. Raap U, Stiesch M, Reh $H$, et al. Investigation of contact allergy to dental metals in 206 patients. Contact Dermatitis 2009; 60:339-43.

14. Tiwari SM, Gebauer K, Frydrych AM, Burrows S. Dental patch testing in patients with undifferentiated oral lichen planus. Australas J Dermatol 2018;59:188-93.

15. Koch P, Bahmer FA. Oral lesions and symptoms related to metals used in dental restorations: a clinical, allergological, and histologic study. J Am Acad Dermatol 1999;41:422-30.

16. Magnusson B, Blohm SG, Fregert S, et al. Routine patch testing. IV. Supplementary series of test substances for Scandinavian countries. Acta Derm Venereol 1968;48:110-4. 